\title{
BIMBINGAN EMOSIONAL MENGEMBANGKAN KEMAMPUAN ANAK-ANAK
}

\author{
Farida
}

Jurusan Tarbiyah STAIN Kudus

\begin{abstract}
Children phase has a variety of potential ability to be optimized in order to undergo all development tasks in line with the maximum growth, so ready to enter the next phase, namely: teenagers, adults, elderly. Cognitive potential to solve problems in life, emotional potential to adapt to the environment, and the children potential psychomotor is able to realize what he was thinking and feeling fit the norm for a man who is always active "go-no" to independence responsible. Therefore, education and counseling is done by adults (especially parents) for children to grow up to be independent human beings and with all his typical late can be tried in the hope that always "successful". Modeling, habituation, giving guidance to understand the characteristic of the child will be more effective. The trick is to give "free" experience and play while learning among friends. The conditions for children have needs besides socializing with family get ready to enter formal educational institutions and non-formal, and various ways to respect the diversity of the environment. Hence the need for the feeling to feel fulfilled in the guidance of emotional given to children to be able to manage the basic emotions (happy, sad, disgusted, angry, disappointed, and surprised) that is held to be a human being adaptable, motivated and self-esteem and self-concept positive. Due to the positive expression of emotion to motivate children to develop cognitive abilities and psychomotor personal-social and spiritual.
\end{abstract}

Keywords: emotional guidance, children skills

\section{A. Pendahuluan}

Memiliki rasa ingin tahu yang tinggi, tidak ada rasa lelah dan menyerah untuk mendapatkan sesuatu (mainan), selalu berpikir konkret untuk mengenal lingkungan sekitar, selalu bermain, asyik mendengarkan dongeng atau cerita, memfantasikan diri menjadi dan pada situasi tertentu, dan lain-lain merupakan kondisi yang pada umumnya dialami oleh anak-anak. 
Sehingg mengenal dunia anak adalah menyenangkan dan penuh kebebasan namun tetap terkontrol "pengawasan" orang dewasa. Seluruh kemampuan anak-anak akan teraktual ketika diberikan kesempatan pengalaman dan pembiasaan oleh orang dewasa (orang tua) yag akan menjadikan anak-anak mampu berimitasi dan menjadikan "suri tauladan" orang tua sebagai orang pertama dalam memberikan pendidikan (bimbingan) untuk optimalisasi kemampuan kognitif dengan berlatih menyelesaikan masalah, kemampuan afektif dengan berlatih menghormati sesama manusia dan menghargai keBhineka-an, serta kemampuan psikomotorik dengan berperilaku yang sesuai dengan lingkungan sekitar. Oleh karena itu, anak-anak sebagai generasi penerus perjuangan bangsa berhak untuk mendapatkan pendidikanbimbingan-pengalaman di lembaga informal-formal-non formal.

Hakikat pendidikan adalah menyediakan lingkungan yang memungkinkan anak-anak untuk mengembangkan bakat, minat dan kemampuannya secara optimal dan utuh mencakup kognitif, afektif, dan psikomotorik (Syah, 2011: vi). Seperti yang ada pada kelas Miss Ansel: Bagi anak-anak taman kanak-kanak di kelas Miss Ansel, hari itu merupakan hari istimewa. Ini tidak berarti bahwa hari-hari lain tidak istimewa dalam ruangan yang penuh dengan lukisan dinding berwarna-warni cerah itu dan juga sebuah lokomotif mainan yang amat besaryang digunakan sebagai ruang baca sekaligus rak-rak yang penuh dengan buku dan mainan. Tetapi hari itu kelas tersebut akan menerima tamu penting yang akan mengajak memainkan suatu permainan yang menyenangkan dan setiap anak mendapatkan giliran. Barry, empat tahun adalah anak pertama yang terpilih untuk memainkan permainan yang sengaja dirancang agar terlalu sulit bagi anak-anak. Tamu itu seorang peneliti dalam bidang perkembangan anak, menunjukkan pada Barry sebuah bola logam mengilap yang diletakkan pada pelatyang terpasang pada sebuah menara. "Ini mirip lift," katanya. "Kau harus menaikkan pelat ini kepuncak menara tanpa menjatuhkan bola kecilnya. Pada usaha 1,2,3 dan ke 4 gagal. "Apakah menurutmu kau akan sanggup melakukannya?” tanya tamu itu dengan nada netral. "Oh, pasti!" sahut Barry dengan bersemangat sambil mencoba lagi. Barry kurang lebih sama dengan kebanyakan anak-anak lain di kelas taman kanak-kanak itu yang diikutsertakan dalam eksperimen tentang motivasi diri. walaupun tiap anak yang mendapatkan giliran mencoba menaikkan bola dan selalu gagal meski berulang-ulang, masing-masing mengaku bahwa ia pada akhirnya akan berhasil (Shapiro, 1997: 4).

Kondisi di kelas Miss Ansel merupakan salah satu bukti bahwa dunia anak adalah penuh semangat dan keyakinan akan kemampuan 
untuk berhasil. Rasa percaya diri yang penuh semangat dan keyakinan akan tetap terjaga pada fase perkembangan berikutnya ketika orang tua mampu untuk memberikan reinforcement positif atas semua usaha, tidak boleh terbebani dengan hasil. Karena proses untuk meraih keberhasilan merupakan pengalaman bagi anak-anak untuk menyelesaikan permasalahan dengan kemampuan yang dimiliki juga sebagai pengalaman untuk berlatih menerima ketidakberhasilan dengan cepat beradaptasi mengumpulkan semangat untuk berusaha kembali. Oleh karena itu, reward berupa pujian dan dukungan merupakan sumber energi yang menjadikan anak-anak untuk terus berusaha dengan pikiran yang jernih dan penuh semangat.

Semua manusia lahir di dunia dengan pikiran jernih dan keyakinan bahwa segala sesuatu mungkin untuk diwujudkan. Semua hal adalah positif dan baik. Ingat ketika masih anak-anak, bisa melakukan dan menjadi segalanya tanpa batas meskipun bimbingan tetap dilakukan agar perilaku anak-anak sesuai dengan norma. Namun, saat tumbuh dewasa, manusia terkontaminasi dengan keyakinan, ketakutan, keterbatasan dari lingkungan dan rekan-rekan, tingkat kompetisi, yang kesemuanya secara bertahap membentuk diri pribadi manusia "yang baru". Sayangnya, banyak kepercayaan yang bersifat negatif dan membatasi tindakan dan keberadaan manusia seutuhnya. Hal tersebut seringkali menyebabkan ketidakbahagiaan atau perasaan tidak terpenuhi dalam kehidupan sehari-hari (Claproth, 2010: 138) yang bahkan mengganggu optimalisasi kemampuan-kemampuan yang dimiliki anak. Menjadi tantangan bagi semua orang dewasa untuk bisa memahami kebutuhan dan kondisi anak-anak agar potensi-potensi kemampuan yang dimiliki dapat teraktualisasi, salah satunya dengan bimbingan emosional yang menyenangkan agar anak-anak dapat mengelola emosi dan mengaktualisasikan ekspresi emosi dengan baik. Bahkan diajarkan tentang mengenal dan mengekspresikan emosi dasar yang dimiliki oleh setiap manusia, yaitu: gembira, sedih, jijik, marah, kecewa, dan terkejut. Emosi dasar dimiliki oleh setiap anak, dan membutuhkan bimbingan agar ekspresi emosi tidak berdampak negatif dan merugikan.

Sejak lahir anak adalah makhluk yang aktif dan suka bereksplorasi, oleh sebab itu anak harus dibiarkan untuk memperoleh pengetahuan dengan caranya sendiri melalui interaksinya dengan lingkungan, baik dengan sesama manusia maupun interaksi dengan hewan dan tumbuhan. Menurut Rousseau, bila anak dibiarkan berkembang secara wajar "alami" maka perkembangannya akan berjalan mengikuti tahapan yang teratur. 
orang tua dan pendidik adalah membimbing sesuai yang telah diatur alam secara spontan (Desmita, 2013: 15) sesuai kebutuhan dan ke-khas-an anakanak. Maka pengalaman tumbuh kembang yang menyenangkan bagi anak akan cenderung diulang dan menjadi perilaku yang berpengaruh positif pada semua kemampuan anak-anak (kognitif, afektif, psikomotorik), karena kemampuan merupakan deskripsi dari kepribadian yang teraktual dalam perilaku keseharian.

Pribadi yang integral dapat dilihat dari berfungsinya kognitif, afektif dan psikomotorik secara harmonis yang menjadikan anak-anak berprestasi dan mampu beradaptasi dengan lingkungan dengan keunikan dan keragaman kejiwaan dalam mewujudkan gejala-gejala jiwa, yaitu: pengamtaan, fantasi, berpikir, ingatan, perasaan, emosi, motivasi, inteligensi, persepsi, dan kesadaran. Kebutuhan anak dalam mengekspresikan gejala jiwa dapat berimitasi dan menjadikan lingkungan (orang dewasa) menjadi sumber suri tauladan. Karena tidak seorangpun dapat mengetahui, bagaimana bentuk jiwa itu, bagaimana ia melekat pada tubuh orang yang hidup, dan bagaimana ia meninggalkan tubuh yang mati. Namun yang dapat diketahui oleh manusia hanyalah gejala-gejala jiwa yang tampak dari indikator perilaku yang pengaruhnya kelihatan pada sikap, gerak-gerik dan tindak-tanduk manusia (Abu Ahmadi dan Noor Salimi. 2004. hal. 13) yang dipelajari dan telah banyak hasil penelitian jiwa manusia dalam lingkup psikologi.

Menurut Aristoteles menyebut dengan "The Anima" yaitu: anima vegetativa pada tumbuh-tumbuhan, anima sensitiva pada hewan, dan anima intelektiva pada manusia (namun semua anima ada pada manusia). Sehingga pada manusia juga terdapat insting (kemampuan bawaan) yang dimiliki dan akan berkembang sesuai stimulasi lingkungan (orang, kondisi sosial, dan upaya pendidikan informal-formal-non formal). Oleh karena itu, tugas orang dewasa dan lingkungan untuk menstimulasi semua daya yang telah dimiliki manusia agar mencapai kesempurnaan. Baik daya-daya fisik (kekuatan), psikis (keberanian) maupun religius (keyakinan). Selain menstimulasi adalah memberikan bimbingan emosional agar anak-anak mengenali diri sendiri untuk mengembangkan berbagai kemampuan untuk menjadi manusia seutuhya melalui berbagai media dan metode pembelajaran yang sesuai untuk usia anak-anak. Karena media yang bervariatif dan berwarna mencolok, metode dongeng dan cerita, dengan suasanan bermain yang menyenangkan akan menarik perhatian anak-anak untuk belajar tentang hidup dan kehidupan, baik tentang dirinya sendiri maupun orang lain serta lingkungan alam semesta. Oleh karena itu, menjadi kewajiban bagi orang 
tua untuk senantiasa memberikan bimbingan kepada anak-anak yang dalam tahapan tumbuh kembang.

Dasar pemikiran bimbingan bukan semata-mata terletak pada ada atau tidaknya landasan hukum "perundang-undangan", melainkan yang lebih penting adalah menyangkut upaya memfasilitasi: menstimulasi bakat-minat yang dimiliki anak-anak dan membimbing untuk mengarahkan perilaku anak-anak sesuai dengan norma. Upaya bimbingan emosional yang diberikan kepada anak-anak untuk mengembangkan potensi diri dalam mencapai tugas-tugas perkembangannya menyangkut aspek fisik, emosi, intelektual, sosial dan moral-spiritual. Dengan pemahaman bahwa anak adalah seorang individu yang sedang berada dalam proses berkembang atau menjadi (on becoming) yang selalu progresif ke arah kematangan atau kemandirian, anak memerlukan pengarahan dan bimbingan.

Rasa suka ataupun tidak suka, rasa senang atau tidak senang merupakan hal yang sering dialami oleh anak-anak dalam mengenal lingkungan (manusia ataupun benda), sehingga bimbingan emosional sangat tepat diberikan sejak dini agar anak-anak yang rasa ingin tahunya sangat tinggi dapat terarah dalam mengaktualisasikan kemampuankemampuan yang dimiliki. Meskipun dalam kenyataannya ada keterbatasanketerbatasan dari lingkungan yang menyebabkan anak-anak tidak dapat menikmati masa kecilnya, misalnya: kurang perhatian dan kasih sayang dari orang tua, tiadanya pendidikan dan arahan dari orang dewasa, keterbatasan ruang bermain bagi anak-anak, media dongeng yang tidak dimanfaatkan dan lain-lain. Hal tersebut yang menjadikan proses tumbuh kembang seluruh kemampuan anak tidak selalu berlangsung secara mulus atau bebas dari masalah. Dengan kata lain, proses perkembangan anak tidak selalu berjalan alur linier, lurus atau searah dengan potensi, harapan, dan nilai-nilai yang dianut. Untuk itu, anak-anak memerlukan bimbingan dalam pemahaman atau wawasan tentang dirinya dan lingkungannya, juga pengalaman dalam menentukan arah kehidupannya (Hamdani, 2012: 5) .Dan menjadi tanggung jawab semua orang dewasa agar anak-anak mampu menyelesaikan tugas perkembangannya dan siap untuk memasuki fase berikutnya.

Mendidik, yang pada tataran praktis adalah membimbing dan mengarahkan anak-anak. Kewajiban setiap orang tua untuk memprsiapkan masa depan yang gemilang dan tidak ada lagi kekhawatiran terhadap masa depannya, yaitu: baik, sehat, daya juang, yakin akan kemampuan dan berdimensi spiritual yang tinggi. Semua prestasi itu tidak mungkin diraih orang tua tanpa pendidikan yang baik. Secara sosial psikologis, keterlibatan 
orang tua dalam mendidik dan membimbing anaknya adalah tuntutan sosial dan kejiwaan. Sebab pada umumnya setiap individu berkeinginan memiliki posisi terhormat dihadapan orang lain dan meyakini kehormatan adalah kebutuhan naluri insaniyah. Sehingga anak adalah simbol sosial dan kebanggaan psikologis orang tua dilingkungan sosial (Rohmah, 2013: 109). Bahkan norma individu pada anak merupakan norma yang diajarkan dan dibiasakan oleh keluarga. Misalya: melatih kedisiplinan sejak usia anak-anak agar muncul pemahaman akan kejelasan aturan dan sanksi, membiasakan berperilaku sopan santun antar anggota keluarga, saling menghargai perbedaan individu seluruh anggota keluarga, saling menyayangi dan senantiasa memberikan dukungan untuk terus berprestasi sesuai dengan aktivitas masing-masing anggota keluarga. Kondisi keluarga tersebut memberikan pengalaman emosional serta bimbingan emosional secara langsung ataupun tidak bagi anak-anak untuk siap berkompetisi di lingkungan dengan berbagai kemampuan (kognitif, afektif, psikomotorik maupun pribadi, sosial, spiritual) yang dioptimalkan.

\section{B. Pembahasan}

Membahas tentang emosional pada anak-anak merupakan hal yang menarik karena merupakan fitrah tiap manusia untuk dibantu dikembangkan oleh lingkungan, karena dengan kemampuan emosional maka anak akan melatih diri untuk menerima diri sendiri dan percaya diri dalam berinteraksi. Anak-anak membutuhkan bimbingan untuk mengenal dan mengoptimalkan seluruh potensi yang dimiliki agar siap untuk melaksanakan tugas-tugas perkembangan dan berkompetisi dengan sesama dalam berprestasi sesuai kemampuan masing-masing. Karena setiap anak memiliki perbedaan individu, meskipun kebutuhan dan rasa ingin tahu yang khas serta karakteristik secara umum adalah sama. Menjadi bekal bagi orang dewasa khususnya orang tua dalam mengoptimalkan tumbuh/fisik dan kembang/psikis anak-anak.

Berdasarkan hasil penelitian tentang neurolog dan psikolog menunjukkan bahwa kecerdasan emosional sama pentingnya dengan kecerdasan intelektual. Menurut Goleman bahwa setiap manusia memiliki dua potensi pikiran, yaitu pikiran rasional dan pikiran emosional. Kecerdasan emosional merujuk kepada kemampuan mengenali perasaan sendiri dan orang lain, kemampuan memotivasi diri sendiri, kemampuan mengelola emosi dengan baik pada diri sendiri dan dalam hubungan dengan orang lain. Sehingga dengan kestabilan emosi maka anak-anak akan berlatih untuk 
menerima kondisi diri dan percaya diri dalam berinteraksi untuk memenuhi kebutuhan pribadi, sosial dan spiritual. Kemampuan untuk memenuhi kebutuhan sesuai dengan kondisi kejiwaan yang seimbang menunjukkan bahwa seseorang memiliki kestabilan emosi.

Kecerdasan emosi sangat dibutuhkan untuk mencapai kesuksesan. Terbukti pada anak-anak yang memiliki kecerdasan emosi yang tinggi akan lebih percaya diri, lebih bahagia, populer dan sukses. Anak-anak lebih mampu menguasai emosinya dapat menjalin hubungan yang baik dengan orang lain, mampu mengelola stres dan memiliki kesehatan mental yang baik, dan disukai oleh lingkungan (Desmita, 2013: 172) yang akan teroptimal semua kemampuan. Oleh karena itu, bimbingan emosional sangat dibutuhkan anak-anak dan menjadi kewajiban orang dewasa untuk membantu anakanak mengenali dan melatih ekspresi emosi agar mampu beradaptasi di lingkungan menjadi manusia yang normal. Karena ketidakmampuan beradaptasi menjadikan seseorang sulit untuk belajar dan berpengalaman yang menimbulkan penyimpangan baik (personal, sosial, spiritual). Sehingga bimbingan selalu dibutuhkan anak-anak untuk mengaktualkan potensi-potensi kemampuan yang dimiliki agar menjadi anak yang mudah beradaptasi dimanapun dan dengan siapapun. Oleh karena itu, pendidikan merupakan kebutuhan setiap manusia untuk mengenali seluruh potensi dan mengoptimalkan kecerdasan yang dimiliki. Maka, idealnya pendidikan akan menjadikan manusia sempurna untuk melaksanakan tugas hidup dan kehidupan untuk mencetak anak-anak bangsa yang cerdas dan berbudi pekerti serta berperilaku normal.

Sangatlah banyak faktor dan sebab yang membawa kepada penyimpangan, kegoncangan dan dekadensi moral, dan buruknya sistem pendidikan yang ada di tengah-tengah masyarakat yang penuh dengan kedurhakaan dan dosa dalam kenyataan yang sungguh mengenaskan, banyak bibit kejahatan dan kerusakan yang mengitari anak-anak, remaja hingga orang dewasa dan menyerang mereka dari berbagai arah (Adz-Dzaky, 2004: 342), sehingga pendidikan memiliki peran penting dalam membimbing anak-anak untuk mengembangkan potensi anak-anak yang dimiliki untuk menjadi manusia yang normal. Karena dengan pendidikan maka anak-anak dalam belajar ilmu pengetahuan di ranah kognitif, mampu memahami dan mengekspresikan emosi di ranah afektif yang sesuai dengan individu lainnya, serta kemampuan integral antara apa yang dipikirkan-dirasakan-dilakukan di ranah psikomotorik ketika berinteraksi dengan lingkungan sosial.

Banyak pakar sosial percaya bahwa masalah anak, pada era globalisasi 
(budaya serba cepat, canggih, instant) ini dapat dirunut ke peliknya perubahan-perubahan pola sosial yang telah terjadi dalam empat puluh tahun terakhir, termasuk meningkatnya angka perceraian, meresapnya pengaruh negatif TV dan beragam media sosial, kurangnya rasa hormat kepada sumber otoritas, semakin sedikitnya waktu yang disediakan orang tua untuk anak-anak, pengabaian kasih sayang, kurang adil dalam memberikan reward dan punishment pada perilaku anak-anak dan lain-lain. Bila untuk sementara harus menerima kenyataan bahwa perubahan sosial tidak dapat dielakkan, maka pertanyaannya adalah Apa yang dapat dilakukan agar anakanak tumbuh kembang dengan sehat-bahagia-produktif? (Shapiro, 1997: 6). Jawabannya adalah dengan membantu memberikan bimbingan emosional agar optimal semua kemampuan anak-anak sesuai dengan karakteristik dan ke-khas-annya. Karena dengan mengenal potensi emosi dasar maka anak mampu memahami diri sendiri dan menumbuhkan rasa percaya diri dan siap untuk berkompetisi di lingkungan.

Bimbingan emosional tidak membutuhkan ruang dan media khusus, karena setiap manusia memiliki emosi dasar secara bawaan. Sehingga orang tua dapat melatih kebiasaan dan memberikan kesempatan pengalaman langsung dan tidak langsung dalam mengenalkan dan mengekspresikan emosi. Secara naluri, orang tua dapat menjelaskan dan memberikan keteladanan tentang berbagai macam emosi beserta ekspresinya. Dengan mengenal dan mengelola emosi maka anak-anak dapat menyelesaikan semua permasalahan dalam memenuhi kebutuhan rasa ingin tahu, bermain dengan teman sebaya (peer group) dan mendengarkan dongeng dalam mengenal lingkungan. Anak-anak dengan emosi yang stabil akan dapat optimal dalam berpikir dan berperilaku.

Manusia adalah makhluk yang aktif dan memiliki kemampuan untuk selalu meng"ada" sesuai dengan kebutuhan dalam memenuhi rasa ingin tahu mengenal lingkungan. Kondisi tersebutlah yang menjadikan manusia membutuhkan pendidikan dimanapun-oleh siapapun-tentang apapun. Pendidikan memiliki tujuan untuk memandirikan manusia dalam mempertanggungjawabkan tugas ke-khalifahan-nya. Menurut Syah (2011: 1) bahwa pendidikan pada dasarnya adalah usaha sadar untuk menumbuhkembangkan potensi sumber daya manusia dengan cara mendorong dan memfasilitasi kegiatan belajar dengan bimbingan yang dibutuhkan anak-anak. Sesuai UU RI No. 20 Tahun 2003 tentang SisDikNas Bab 1 Pasal 1 bahwa pendidikan didefinisikan sebagai usaha sadar dan terencana untuk mewujudkan suasana belajar dan proses belajar agar anak- 
anak secara aktif mengembangkan potensi dirinya untuk memiliki kekuatan spiritual keagamaan, pengendalian diri, kepribadian, kecerdasan, akhlak mulia, serta ketrampilan yang diperlukan dirinya, masyarakat, bangsa dan negara. Sehingga perubahan dalam pendidikan tidak hanya untuk membantu pertumbuhan dengan memberikan makanan yang bergizi, namun juga dibutuhkan bimbingan untuk membantu perkembangan secara kualitas berprogres untuk menjadi manusia sempurna dengan optimalnya semua potensi yang dimiliki anak-anak.

Kebutuhan dan kejelasan tujuan pendidikan yang harus diberikan sejak dini akan menjadikan anak-anak yang berkualitas. Karena perubahan ilmiah mengenai kualitatif yaitu tentang: tingkat perkembangan, taraf perkembangan, tugas-tugas perkembangan, dan hukum-hukum perkembangan. Tingkat perkembangan adalah satu pembagian masa kehidupan menurut jarak kronologis tertentu, yang berubah-ubah secara tetap. Taraf perkembangan adalah satu periode dalam kehidupan seseorang dengan pemunculan sifat-sifat pembawaan atau pola-pola tingkah laku. Tugas-tugas perkembanagn adalah ketrampilan, tingkat prestasi, dan kemampuan menyesuaikan diri dengan sukses dari seseorang, yang dipengaruhi oleh kematangan psikis, tekanan kultural dari masyarakat, dan hasrat-hasrat pribadi. Sedangkan hukum-hukum perkembangan berkaitan dengan faktor-faktor yang menentukan perkembangan, apakah dari lingkungan, keturunan, ataukah dua-duanya (Mujib, dkk, 20011: 92). Oleh karena itu, kesuksesan pendidikan adalah ketika para pendidik memahami tentang kebutuhan dan ke-khas-an perkembangan pada anak. Dengan pendidikanlah, manusia menjadi sempurna untuk mengoptimalkan seluruh potensi: keyakinan Ilahiyah, kekuatan fisik, ketenangan psikis, dan penyesuaian sosial.

Di dalam pertumbuhan dan perkembangan manusia sejak dilahirkan hingga menjadi dewasa, fitrah Ilahiyah sering kurang menjadi perhatian, sehingga ia tidak dapat turut eksis dalam setiap perkataan, perbuatan, sikap dan gerak-gerik. Alam materi sangat mendominasi dalam kehidupan manusia; seluruh prilaku, sikap dan aktifitas hidup mencari materi dengan segala keindahan dan daya tariknya. Karena hal demikian itulah maka fitrah menjadi terbelenggu dalam dada yang paling dalam, ia hanya bersedih dan menangis, dan tidak dapat terbang bebas membawa kecenderungan yang taat dan tunduk kepada Sang Maha Pencipta-Nya. Keadaan seperti itulah yang membuat manusia menjadi gelisah, galau, cemas dan ketakutan; dan itulah fitrah Ilahiyah. Oleh karena itu, orang dewasa (khususnya orang tua) 
memiliki tanggung jawab utama untuk mendidik anak dalam menguatkan akidah "ke-Esa-an Allah", yang akan menumbuhkan kesadaran awal anakanak bahwa belajar mengenal lingkungan adalah perintah Allah bagi setiap manusia dari turun ayunan sampai masuk ke liang lahat. Dengan belajar maka seluruh kemampuan yang dimiliki manusia dapat terasah dan siap untuk berkompetisi ketika beradaptasi dengan tuntutan lingkungan.

Rasulullah SAW. bersabda, bahwa setiap anak yang dilahirkan dalam kondisi suci tanpa dosa. Kemudian kelak dalam perkembangannya ia akan menjadi tetap suci atau tidak tergantung usaha dan daya upaya kedua orang tuanya; apakah ia akan menjadi seorang mukmin atau muslim yang sejati lagi tangguh, atau akan menjadi Yahudi, Nasrani dan Majusi. Oleh karena itu, orang tua memiliki tanggung jawab dan amanah untuk membantu anak-anak dalam aktualisasi fitrah dan potensi-potensi kemampuan yang dimiliki anak. Karena penyimpangan fitrah akan menjadikan anak-anak yang memiliki berbagai penyimpangan bahkan berdampak pada perilaku yang tidak sesuai dengan norma. Karena manusia akan menyimpang dari perintah-perintah Allah dan tidak ada kepedulian untuk melakukan kebaikan untuk sesama makhluk (manusia, hewan, dan tumbuhan). Misalnya: tidak bertakwa dalam beragama dan berperilaku merugikan di lingkungan.

Para pendidik sangat bertanggung jawab terhadap problema dekadensi mental, spiritual, moral masyarakat. Jika para pendidik tidak memiliki rasa tanggung jawab dan tidak memiliki sifat amanah yang sejati, serta tidak dapat mengetahui dan memahami sebab-sebab penyimpangan dan faktor-faktor pendorongnya, tidak peka dan tidak segera mengambil inisiatif penanggulangan dan tindakan preventif, maka tidak ayal lagi, anak, remaja dan akhirnya orang-orang dewasa pun akan menjadi sampah dan sumber penyakit masyarakat, serta akan menjadi virus kerusakan dan kriminalitas. Kondisi tersebut akan merugikan diri sendiri dan merugikan lingkungan, karena manusialah yang memiliki tugas untuk mengelola alam semesta untuk kemakmuran seluruh makhluk hidup. Sehingg tindakan yang harus dilakukan oleh seorang pendidik dan psikolog Islam adalah mencari akar segala permasalahan yang menyebabkan adanya penyimpanganpenyimpangan dan gangguan psikologis pada setiap individu maupun kelompok; setelah itu memberikan solusi-solusi yang mengarah kepada perbaikan, kemanfaatan dan kebenaran yang utuh. Jadi, faktor-faktor utama yang menyebabkan adanya potensi penyimpangan prilaku dan gangguan psikologis pada individu secara internal adalah terfokus pada proses pembuahan, hubungan seks, kondisi psikologis kedua orang tuanya saatdalam 
kandungan serta pendidikan spiritual dalam kandungan yang menyimpang dari tuntutan dan bimbingan Ilahiyah. Sedangkan secara eksternal adalah terfokus kepada tidak ada atau kurangnya pendidikan agama secara dini, mendasar dan mengakar, tidak adanya ketauladanan baik dari kedua orang tuanya atau lingkungannya serta terjadinya dikotomis antara agama, pendidikan dan kehidupan (Adz-Dzaky, 2004: 349). Oleh karena itu, orang tua berkewajiban memberikan pendidikan dan keteladanan pada anak yang dimulai sejak masa konsepsi sampai pada usia remaja, baik pertumbuhan maupun perkembangannya.

Secara sederhana Seifert \& Hoffnung (1994) mendefinisikan perkembangan sebagai “Long term changes in a person's growth, feeling, patterns of thinking, social relationship, and motor skills". Sementara itu, Chaplin (2002) mengartikan perkembangan sebagai: (1) perubahan yang berkesinambungan dan progresif dalam organisme dari lahir sampai mati, (2) pertumbuhan, (3) perubahan dalam bentuk dan dalam integrasi dari bagianbagian jasmaniah ke dalam bagian-bagian fungsional, (4) kedewasaan atau kemunculan pola-pola asasi dari tingkah laku yang tidak dipelajari (Desmita, 2013: 4). Terjadi dari masa konsepsi (pre natal) sampai post natal (bayi, kanak-kanak, anak-anak, remaja, dewasa, tua, lansia). Pada pembahasan ini tentang usia anak-anak yang dioptimalkan kemampuan dengan memberikan bimbingan emosional untuk mewujudkan kecerdasan emosional anak-anak agar seluruh kemampuan anak-anak berkembang secara optimal.

Masa anak-anak adalah masa sebelum berusia 12 tahun. Menurut Kohnstamm, tahap perkembangan kehidupan anak dibagi menjadi, yaitu:

1. Umur 0-3 tahun, periode vital atau menyusui.

2. Umur 3-6 tahun, periode estetis atau masa mencoba dan masa bermain.

3. Umur 6-12 tahun, periode intelektual (masa sekolah).

Sedangkan menurut Elizabeth B. Hurlock merumuskan tahap perkembangan anak secara lengkap, sebagai berikut:

1. Masa prenatal, saat terjadinya konsepsi sampai manusia lahir.

2. Masa paranatal (neonates, saat kelahiran sampai akhir minggu kedua.

3. Masa bayi, akhir minggu kedua sampai akhir tahun kedua.

4. Masa kanak-kanak awal, umur 2-6 tahun.

5. Masa kanak-kanak akhir, umur 6-11 tahun.

Dapat dipahami bahwa fase-fase pertumbuhan dan perkembangan hidup manusia di dunia ini dimulai dengan masa bermain (0-7 tahun), masa melalaikan dan masa sendau gurau (7-12 tahun). Pada usia anak 
membutuhkan orang lain, yang paling pertama dan utama yang bertanggung jawab adalah orang dewasa khususnya orang tua (Rohmah, 2013: 91). Sehingga orang tua wajib memberikan pendampingan dalam pertumbuhan dan perkembangan anak dalam menjalankan tugas perkembangan sesuai keunikan karakteristik anak masing-masing untuk optimalisasi aspek kognitif-afektif-psikomotorik secara seimbang. Karena semua kecerdasan yang integral dibutuhkan, yaitu: kecerdasan kognitif untuk mengetahui ilmu pengetahuan, kecerdasan afektif dalam membentuk rasa percaya diri, dan kecerdasan psikomotorik untuk memudahkankan individu dalam bersikap yang adaptif di lingkungan. Namun beberapa dasawarsa yang lalu (dan di Indonesia sampai sekarang pun masih), lebih mengutamakan pengembangan kecerdasan inteligensi atau IQ (Syah, 2011: vi).

Pendidikan dan bimbingan yang dilakukan oleh orang tua lebih pada kemampuan kognitif dan psikomotorik anak sering menjadi bagian yang diperhatikan, dan distimulasi optimal. Namun sebagian besar kurang peka akan tahapan perkembangan otak emosi bahwa tiap keterampilan emosional mempunyai jadwal perkembangan masing-masing. Karena kenyataannya tidak adanya antisipasi perubahan-perubahan dalam perkembangan emosi anak-anak sebagaimana memandang perubahan-perubahan dalam pertumbuhan fisik dan kognitif (Shapiro, 1997: 23). Padahal, secara khusus dalam pembelajaran, orang tua dan pendidik sebagai pengajar, pembimbing untuk memahami seluruh aspek anak-anak, yaitu: kecerdasan dan bakat khusus, prestasi, perkembangan jasmani dan kesehatannya, kecenderungan emosi dan karakteristiknya, sikap dan minat belajar, cita-cita, kebiasaan belajar dan bekerja, hobi dan penggunaan waktu senggang, hubungan sosial, kebiasaan keluarga, lingkungan sosial, sifat-sifat khusus, dan kesulitan yang dialami anak-anak (Asril, 2013: 19). Maka sekarang makin disadari pentingnya kecerdasan emosional. Oleh karena itu, orang dewasa mulai memberikan bimbingan dan arahan agar anak-anak mengenal lingkungan dengan pendekatan afektif (emosional) yang dilakukan dengan memahami karakteristik yang khas pada anak dengan memahami berbagai potensi emosi dasar dan pengalaman dalam mengekspresikan emosi serta mengelola emosi agar integral apa yang dipikirkan-dirasakan-dan yang dilakukan. Oleh karena itu, orang tua memberikan keteladanan dan kesempatan pada anakanak untuk senantiasa belajar.

Memberitahu anak bahwa tidak ada jalan lain untuk menjadi pintar selain belajar dan belajar dengan memupuk rasa ingin tahu dan keinginan terus maju akan menjadi faktor internal anak-anak. Agar anak dapat belajar 
dengan baik, maka harus berkonsentrasi dengan dukungan dari suasana sekitar, yaitu: dimana, kapan, dan bagaimana anak-anak dapat belajar dengan efektif (Claproth, 2010: 177) ketika bimbingan emosional melalui: keterlibatan, pembebasan, kesempatan bermain, pendekatan bercerita/ mendongeng untuk mengembangkan kemampuan-kemampuan anak. Berdasarkan aspek-aspek kecerdasan emosional yang perlu dilakukan untuk memberikan bimbingan kepada anak-anak, yaitu:

- Dorong anak untuk mengungkapkan perasaan melalui kata-kata sebagai upaya untuk mengatasi konflik dan kesusahan dan agar kebutuhan anakanak terpenuhi. Kondisi tersebut melatih anak untuk percaya diri dalam berpendapat, dan bagaimana lingkungan memberikan dukungan atau penolakan terhadap sebuah pendapat, baik melalui komunikasi verbal maupun non verbal. Sehingga anak-anak terlatih memiliki kepribadian yang utuh karena adanya kesesuaian antara ucap-rasa-sikap.

- Ajari anak ketrampilan mendengar aktif untuk membantu mengembangkan hubungan yang secara emosional saling memberi pada saat sekarang dan di kemudian hari (Shapiro, 1997: 282). Sehingga anak-anak memahami tentang kebutuhan diri sendiri dan kebutuhan orang lain, ada saatnya menyampaikan pendapat namun juga ada kalanya mendengarkan pendapat orang lain. Kondisi tersebut melatih anak untuk mengurangi "ego aku”, misalnya: ibu ku, bapak ku, mainanku terganti dengan ibu kita, bapak kita, mainan bersama.

Kesempatan untuk mengekspresikan emosi senang ataupun emosi sedih memberikan pemahaman pada anak-anak bahwa reaksi emosi sesuai dengan stimulusnya serta disesuaikan dengan siapa atau di mana ekspresi emosi tersebut. Bahkan menyadarkan anak-anak bahwa kondisi emosi akan membangkitkan energi untuk beraktivitas, sehingga bimbingan emosional akan mengarahkan pengelolaan energi emosi pada hal-hal yang bermanfaat (berdampak positif). Misalnya: ekspresi marah dengan berolah raga lari, ekspresi sedih dengan menuliskan, ekspresi kecewa dengan memfantasikan diri menjadi lebih baik pada kondisi keberhasilan dan lain-lain.

Emosi sebagai reaksi penilaian (positif atau negatif) yang kompleks dari sitem syaraf seseorang terhadap rangsangan dari luar atau dari dirinya sendir. Sehingga emosi diawali dengan adanya suatu rangsangan, baik dari luar (benda, mansuia, situasi, cuaca) maupun dari dalam diri (tekanan darah, kadar gula, lapar, ngantuk, segar dan lain-lain pada panca indra manusia). Selanjutnya manusia menafsirkan persepsi atas rangsangan sebagai suatu 28 hal yang positif (menyenangkan atau menarik) atau negatif (menakutkan, 
ingin menghindar) yang selanjutnya diterjemahkan dalam respon-respon fisiologik dan motorik (jantung berdebar, mulut menganga, bulu roma berdiri, mata merah dan sebagainya dan pada saat itulah terjadi emosi (Sarwono, 2012: 124). Sehingga potensi emosi dasar dimiliki oleh setiap manusia yang dibutuhkan bimbingan agar reaksinya tidak merugikan diri sendiri dan orang lain, bahkan reaksi emosi (munculnya energi yang lebih) dapat diarahkan dengan bimbingan emosional untuk melakukan aktivitas yang positif yang diawali dengan lebih mengenali diri sendiri yang. Oleh karena itu, bimbingan emosional dapat diajarkan lebih dini kepada anakanak untuk mengasah seluruh kemampuan kognitif-afektif-psikomotorik sesuai dengan kebutuhan dan keunikan masing-masing.

Anak-anak pada dasarnya mempunyai ke-khas-an sifat, yaitu: percaya diri yang alami, bahkan ketika menghadapi sesuatu yang mustahil dan kegagalan yang berulang. Sebagai penemu pertama eksperimen menara, Deborah Stipek menulis, hingga usia enam atau tujuh tahun, anak-anak menaruh harapan yang tinggi untuk berhasil meskipun kinerja pada usahausaha yang dilakukannya hampir selalu buruk. Ciri-ciri yang muncul pada anak-anak, yaitu: keuletan, optimisme, motivasi diri dan antusiasme adalah bagian dari kecerdasan emotional. EQ bukan didasarkan pada kepintaran anak, melainkan pada sesuatu yang dahulu disebut karakteristik pribadi. Penelitian sekarang menemukan bahwa ketrampilan sosial dan emosional lebih penting bagi keberhasilan hidup (Shapiro, 1997: 4). Oleh karena itu, anak membutuhkan bimbingan emosional untuk melatih kemampuankemampuan yang dimiliki agar teraktual dalam kehidupan keseharian. Sehingga bimbingan emosional dapat dilakukan orang dewasa dengan berbagai media cerita dongeng, pembebasan pengalaman dalam beragam situasi, kejelasan aturan dan sanksi, dilatihkan dengan suasana bermain yang menyenangkan, serta pembiasaan keteladanan disesuaikan dengan gaya belajar seorang anak. Yang secara terprogram, anak-anak sampai usia tujuh tahun tumbuh dengan sifat percaya diri akan kemampuan.

Potensi emosi yang dimiliki anak dimulai dengan kenyamanan pada figur lekat (terutama ibu) karena terjalin hubungan emosional sejak di dalam kandungan. Yang dilanjutkan dengan membangun hubungan emosional yang lebih intensif pada proses para natal dan post natal. Hubungan emosional dengan anak-anak terwujud dalam kondisi, yaitu:

- Perlakuan sebagai manusia sederajat.

- Mengetahui apa yang disukai, cara berpikir dan berperasaan mengenai hal-hal yang terjadi dalam kehidupan anak-anak. 
- Membayangkan apa yang anak-anak katakan kepada diri sendiri, mengenai diri sendiri.

- Mengetahui apa yang menghambat anak-anak untuk memperoleh hal yang benar-benar diinginkan.

- Berbicara dengan jujur kepada anak-anak dengan cara membuat anakanak mendengarnya dengan jelas dan halus.

- Bersenang-senanglah bersama anak-anak (Desmita, 2013: 173).

Kondisi tersebut dapat diciptakan dimanapun oleh orang tua di bimbingan informal, oleh guru pada bimbingan formal serta dukungan masyarakat di lingkungan sosial. Oleh karena itu, kerjasama orang tua dengan guru dan anggota masyarakat akan menjadikan anak-anak tumbuh dan kembang sesuai dengan keunikan dan keyakinan berhasil dalam meraih keinginan dan mewujudkan cita-cita.

Anak-anak tidak membedakan antara upaya dan kemampuan, selama mau mencoba maka semua anak yakin akhirnya akan berhasil. Namun ketika naik ke kelas tiga, mulai sadar bahwa sebagian anak lebih mampu atau tidak mampu. Sehingga anak-anak mulai menyadari bahwa jika ingin sama berhasilnya dengan kawan-kawannya, harus berusaha lebih keras dan memiliki semangat untuk meraih cita-cita. Kesadaran bahwa usaha dapat menjadi kompensasi untuk kemampuan merupakan faktor penting pada anak-anak antara usia 8 dan 12 tahun, dan ini mungkin salah satu resep penting untuk membesarkan anak (mengoptimalkan kemampuankemampuan) yang ulet dalam menghadapi kesulitan. Jika mengantisipasi perubahan dalam proses pertumbuhan, dan menghargai upaya dan bukannya prestasi anak-anak semenjak hari pertama bersekolah, kemungkinan besar anak-anak akan mempunyai kebiasaan belajar yang baik dan ketrampilanketrampilan lain yang berhubungan dengan semua tugas-tugas (Shapiro, 1997: 24) perkembangan yang harus dituntaskan agar anak-anak siap untuk memasuki fase perkembangan berikutnya (remaja, dewasa, tua, lansia). Sehingga membantu perkembagan anak-anak untuk optimalisasi kognitifafektif-psikomotorik dengan gaya belajar masing-masing dalam memperoleh pengetahuan maupun keterampilan hidup.

Belajar menjadi kebutuhan setiap manusia untuk mengetahui $\varangle$ banyak hal tentang hidup dan kehidupan. Karena hakikat belajar adalah proses perubahan perilaku berkat pengalaman dari kesempatan untuk mendapatkan rasa bebas mencari dan menemukan berbagai pengetahuan. Sehingga kegiatan belajar yang dilakukan anak-anak adalah untuk mencapai 30 perubahan tingkah laku, baik yang menyangkut pengetahuan, ketrampilan 
maupun sikap bahkan meliputi segenap aspek organisme atau pribadi (Asril, 2013: 20) yang disesuaikan dengan gaya belajar masing-masing anak. Gaya belajar dipengaruhi oleh karakteristik anak, karena daya yang dominan apakah audio atau visual atau kinestetik. Sedangkan gaya belajar anak ditentukan oleh tiga hal, yaitu: (1) gaya belajar setiap anak yang unik dipengaruhi oleh gaya berpikirnya mengomunikasikan sesuatu yang ingin diketahui dan sudah diketahui, (2) gaya belajar ternyata ditentukan kecerdasannya, dan untuk itu sangat cocok menggunakan model kecerdasan majemuk dalam membimbing, dan (3) gaya belajar ditentukan oleh konsentrasinya dan hal ini sangat ditentukan oleh preferensi lingkungannya cocok atau tidak. Sehingga dapat diketahui gaya berpikir anak dan jenis kecerdasannya mempunyai korelasi dengan faktor lingkungan untuk mengetahui cara membimbing, mengajar, memotivasi, membantu anak-anak (Claproth, 2010: 168) mengoptimalkan kemampuannya.

Memberikan bimbingan emosional kepada anak sesuai dengan kebutuhan dan kondisi anak untuk mengaktualisasikan kemampuankemampuan. Karena semua anak-anak lebih siap untuk belajar bila muncul perasaan bahwa belajar merupakan kewajiban dan sesuai dengan kebutuhan hidup. Para pendidik, khususnya yang mengajar anak-anak dari kalangan minoritas, yang telah lama mengkritik kurikulum sekolah yang dibakukan, mempertanyakan bagaimana mungkin anak-anak akan termotivasi untuk bersekolah dan belajar jika tidak dapat menghubungkan bahan yang diajarkan dengan masalah dan kebutuhan sehari-hari di kehidupan. Dasar pemikiran dalam kecerdasan emosional adalah bahwa makna sesuatu yang dipelajari merupakan faktor penting yang menentukan penyerapannya (Shapiro, 1997: 238). Oleh karena itu dibutuhkan kemampuan orang tua dalam membimbing yang efektif dan efisien dalam memberikan makna dari setiap yang dipelajari. Belajar adalah untuk mendapatkan pengetahuan yang dapat digunakan untuk menyelesaikan permasalahan dan menjadikan manusia yang adaptif dalam lingkungan sosial. Sehingga anak-anak selalu membutuhkan bimbingan dan arahan dari orang-orang dewasa dalam kehidupan sosial.

Menurut Pulias dan Young (1988), Manan (1990), Yelon and Weinstein (1977) dan dikutip Mulyasa (2005) dalam mengemukakan peran guru, yaitu: sebagai pembimbing yang artinya mengarahkan proses pembelajaran yang berupa perkembangan perjalanan fisik dan mental spiritual anak-anak (Asril, 2013: 11) agar anak-anak mampu menjalankan tugas-tugas kehidupan secara mandiri dan bertanggung jawab. Memberikan bimbingan emosional berati 
membantu anak-anak mengembangkan rasa menguasai dan rasa kendali (kecerdasan emosional) yang akan meningkatkan inisiatif dan kemampuan mengarahkan diri membuat anak mampu mengerjakan lebih banyak hal atas usaha sendiri. Sehingga terbentuklah anak-anak dengan kepribadian yang integral untuk menyelesaikan masalah dan menjalani tugas-tugas kehidupan. Maka dibutuhkan kemampuan pembimbing untuk membentuk anak-anak yang mandiri dan bertanggung jawab melalui kepercayaan akan kemampuan anak serta kesempatan pengalaman melalui keteladanan.

Orang tua kelas menengah Amerika masa kini, semakin cenderung memberi lebih banyak kepada anak-anaknya dan menuntut lebih sedikit. Yang kedua memberikan dukungan hanya bila betul-betul diperlukan dan jangan berlebihan, serta memberi kesempatan menilai diri sendiri (menetapkan sasaran dan rencana pencapaian) untuk meningkatkan rasa memegang kendali atas prestasi anak-anak (Shapiro, 1997: 6) dengan berbagai media dan metode pembimbingan yang sesuai kondisi dan kebutuhan amak-anak. Misalnya bimbingan melalui media pembelajaran untuk mengembangkan kemampuan anak-anak dilakukan agar anak dapat menjadi sosok pribadi manusia Indonesia yang dicita-citakan, seperti tercantum dalam tujuan pendidikan nasional (UU No. 20 tahun 2003) yaitu: beriman dan bertakwa terhadap Tuhan Yang Maha Esa, berakhlak mulia, memiliki pengetahuan dan ketrampilan, memiliki kesehatan jasmani dan rohani, memiliki kepribadian yang mantap dan mandiri, serta memiliki rasa tanggung jawab kemasyarakatan dan kebangsaan (Hamdani, 2012: 6). Hal tersebut sejalan dengan Sabda Rasulullah SAW.: "Setiap anak di lahirkan adalah dalam keadaan suci, kemudian kedua orang tuanyalah yang menjadikan ia Yahudi, Nasrani atau Majusi". (HR. Bukhari dari Abu Hurairah $R A)$. Oleh karena itu, anak-anak membutuhkan bimbingan orang dewasa untuk mengenal kemampuan diri dan tuntutan lingkungannya. Sehingga orang dewasa memiliki tanggung jawab untuk membantu tumbuh kembang anak-anak sesuai dengan prinsip pertumbuhan dan perkembangannya.

Menurut Jalaludin, seorang anak yang tumbuh dewasa memerlukan bimbingan sesuai prinsip yang dimilikinya, yaitu:

- Prinsip Biologis. Secara fisik, anak yang baru dilahirkan berada dalam keadaan lemah. Dalam segala gerak dan tindak tanduknya, anak selalu memerlukan bantuan dari orang dewasa sekelilingnya. Dengan kata lain, anak belum dapat berdiri sendiri, keadaan tubuhnya belum tumbuh secara sempurna untuk difungsikan secara maksimal.

Prinsip tanpa daya. Sejalan dengan belum sempurnanya pertumbuhan 
fisik dan psikisnya, anak yang baru dilahirkan hingga menginjak usia dewasa selalu mengharapkan bantuan dari orang tuanya, anak sama sekali tak berdaya untuk mengurus dirinya sendiri. Oleh karena itu, anak pada masa ini selalu memiliki sifat ketergantungan.

- Prinsip eksplorasi. Kemantapan dan kesempurnaan perkembangan potensi manusia yang dibawa sejak lahir, baik jasmani maupun rohani memerlukan pengembangan melalui pemeliharaan dan latihan. Jasmaninya baru akan berfungsi secara sempurna jika dipelihara dan dilatih. Akal dan fungsi mental lainnya pun baru akan menjadi baik dan berfungsi jika kematangan dan pemeliharaan dapat diarahkan pada pengeksplorasian perkembangannya. Yang semuanya tidak dapat dipenuhi sekaligus, melainkan secara bertahap (Rohmah, 2013: 95).

Semua prinsip bimbingan dapat diterapkan sesuai dengan kondisi dan kebutuhan anak-anak. Karena keberhasilan bimbingan bukan pada pembimbingnya,tetapimunculnyakeinginan dan bertambahnyapengetahuan anak-anak dalam setelah menerima bimbingan. Bimbingan diberikan untuk menumbuhkan kemandirian pada anak, bukan ketergantungan "manja". Bimbingan merupakan kebutuhan anak karena setiap manusia yang lahir ke muka bumi ini telah tercipta dalam keadaan fitrah (suci); nuraninya senantiasa ingin mendapat Tuhannya dan ingin mengikuti agama-Nya; dan fitrah yang telah Allah ciptakan dalam diri setiap manusia tidak akan pernah merubah, ia tetap meyuarakan seruan agar senantiasa kembali kepada kebenaran Ilahiyah.

Jelek dan buruknya perilaku dan perbuatan seorang manusia, tetapi hati nuraninya tetap hidup dalam dada, hanya saja gaungnya tidak dapat menembus dinding-dinding jiwa, akal fikiran, qalbu, inderawi dan fisiknya, kecuali kelima hal itu mengalami benturan yang sangat dahsyat dalam perjalanan kehidupannya (Adz-Dzaky, 2004: 351). Yang secara umum dapat dikategorikan dalam kemampuan kognitif, afektif dan psikomotorik. Dan bimbingan emsosional menjadikan keharmonisan aktualisasi keseharian bagi kognitif dan psikomotorik. Karena kecerdasan emosional akan menjadikan anak-anak untuk lebih nyaman serta percaya diri dalam mengoptimalkan kemampuan kognitif dan psikomotorik. Hal tersebut sesuai penelitian yang diselenggarakan di universitas, rumah sakit, klinik di seluruh Amerika Serikat tentang anatomi saraf, perkembangan anak, antropologi sosial, pendidikan, dan psikologi keseluruhan hasilnya tentang ketrampilan emosional misalnya: pemecahan masalah antar pribadi, keuletan, kesetiakawanan, dan empati dapat diajarkan dan dapat mendatangkan perubahan dalam mutu hidup 
anak di kemudian hari.

Komponen-komponen kecerdasan emosional dalam 6 bidang, yaitu: keterampilan yang berhubungan dengan perilaku moral, cara berpikir, pemecahan masalah, interaksi sosial, keberhasilan akademik dan pekerjaan, dan emosi. Tiap bidang umum dibagi dalam ketrampilan kecerdasan emosional, yaitu: motivasi diri, membina persahabatan, empati, berpikir realistis, dan sebagainya. Sehingga orang dewasa (khususnya orang tua) mempunyai penghayatan tentang kecerdasan emosional dan bagaimana membimbing emosional (Shapiro, 1997: 25) untuk optimalisasi kemampuankemampuan anak-anak. Sehingga dengan bimbingan emosional maka anak-anak akan mampu menggunakan kemampuan intelektualnya dengan percaya diri dan bijaksana, serta kemampuan psikomotorik yang sesuai dengan norma.

Beberapa contoh bagaimana para orang tua serta para guru dan profesional dibidang kesehatan mental belajar mempertanyakan tanggapan intuitif, yaitu:

- Psikolog sering menganjurkan orang dewasa membantu anak-anak membicarakan emosi sebagai cara untuk memahami perasaan orang lain. Meskipun kata-kata hanya merupakan sebagian kecil (kurang dari $10 \%)$ dari cara yang dapat digunakan untuk menghasilkan komunikasiemosi yang bermakna.

- Mengembangkan harga diri anak melalui pujian dan dukungan terus menerus seperti yang telah dianjurkan selama 25 tahun oleh para penganut gerakan psikologi kemanusiaan. Membantu anak-anak merasa bahwa dianggap baik hanya berarti jika perasaan-perasaan terkait dengan prestasi-prestasi tertentu dan dengan penguasaan ketrampilanketrampilan baru.

- Stres telah dicap sebagai dampak sampingan yang buruk dari perkembangan teknologi yang membuat manusia serba tergesa-gesa, sehingga dianggap sebagai musuh alami anak-anak (Shapiro, 1997: 21). Oleh karena itu, dengan bimbingan emosional akan membentuk anakanak yang cerdas kognitif-afektif-psikomotoriknya sesuai dengan norma dan kenormalan.

Kewajaran anak-anak dalam berpikir-berperasaan-berperilaku dalam lingkungan sosial menjadi ciri terhindarnya gangguan mental. Karena gangguan kejiwaan (mental) akan sangat terlihat pada sikap dan prilakunya yang telah tertanam sejakia dilahirkan ke muka bumi. Bagaimana perkawinan 34 dan hubungan seks yang dilakukan; setelah dalam masa kehamilan, lahir, 
pendidikan dari nol hingga remaja apakah aktifitas dalam kondisi semua itu melalui metode dan cara yang Allah dan Rasul-Nya ridhai, atau dengan metode dan cara Yahudi, Nasrani dan Majusi (Adz-Dzaky, 2004: 352). Oleh karena itu orang dewasa memiliki kewajiban untuk mengembangkan fitrah Ilahiyah pada setiap anak agar memiliki kemampuan untuk bertakwa kepada Allah dengan pemahaman kognitifnya, rasa senang melakukan, dan kesesuaian perilaku antara apa yang dipahami dengan yang dilakukan. Di mana kemampuan kognitif-afektif-psikomotorik teraktual secara integral. Sehingga untuk mewujudkan kondisi yang seimbang pada anak, maka perlu untuk dibiasakan berpikir dan berperilaku dengan keadaan emosi yang terkendali.

Emosional merupakan suatu reaksi kompleks yang mengait satu tingkat tinggi kegiatan dan perubahan-perubahan secara mendalam serta dibarengi perasaan yang kuat atau disertai keadaan afektif. Dan dapat dipahami bahwa emosi adalah sebagai perasaan atau afeksi yang melibatkan kombinasi antara gejolak fisiologis (seperti denyut jantung yang cepat) dan perilaku yang tampak (seperti senyuman atau ringisan). Dan macammacam ekspresi emosi dasar yaitu: kebahagiaan, perhatian, keheranan, ketakutan, kemarahan, kesedihan, kemuakan sesuai situasinya (Desmita, 2013: 116) yang dapat diajarkan serta dibiasakan agar anak-anak dapat mengelola emosi dengan baik. Misalnya dengan bermain teknik dramatisasi yang memberikan kesempatan bagi anak-anak untuk mengaktualisasikan emosi dasar pada manusia sesuai dengan keteladanan dari orang dewasa disekitarnya.

Dramatisasi adalah teknik pengajaran yang menggunakan ekspresi. Pada dramatisasi ini biasanya anak-anak sendiri sebagai pelaku untuk mendramatisasikan segala peristiwa atau keadaan yang berkenaan dengan pelajaran sejarah atau cerita-cerita masa lampau. Dalam dramatisasi ini anakanak akan aktif dalam permainan atau mereka hanya sebagai penonton dan mendengarkan dengan penuh perhatian. Pengajaran melalui dramatisasi dapat dilakukan dalam bentuk pageant, pantonim, tableau, bermain-main peranan, atau sosio-drama. Keuntungan yang diperoleh dari dramatisasi ini dalam kegiatan belajar mengajar, yaitu:

1. Menyalurkan ekspresi anak-anak ke dalam kegiatan yang menyenangkan.

2. Mendorong aktivitas, inisiatif, dan kreativitas anak sehingga mereka dapat berpartisipasi aktif dalam pelajaran.

3. Memahami isi cerita, karena mereka ikut memainkan peranan di dalamnya. 
Farida

4. Membantu untuk menghilangkan perasaan malu, rendah diri, keseganan, dan kemurungan pada anak.

5. Memupuk rasa saling membantu dan kerja sama antara satu dengan lainnya, juga memupuk perasaan saling mempercayai sesuai dengan kesanggupan masing-masing.

Di dalam teknik dramatisasi, anak-anak akan merasakan kondisi menyenangkan-tumbuhnya motivasi-pemahaman-mengenal kemampuan diri-menghargai orang lain yang kesemuanya merupakan pelatihan dalam mengelola emosi. Oleh karena itu, dramatisasi memberikan kesempatan pada anak-anak untuk mengenali emosi diri sendiri dan emosi orang lain.

Langkah-langkah yang dilakukan dalam pelaksanaan dramatisasi itu adalah; a) mempersiapkan situasi untuk memulai drama, b) menjelaskan kepada anak-anak apa yang diharapkan dari hasil dramatisasi yang dilakukan, c) menugaskan untuk memegang peran tertentu kepada anakanak, d) mengadakan konsultasi dan koordinasi dengan para pelaku, e) pelaksanaan drama, dan f) menilai drama tersebut secara bersama-sama antara pembimbing dengan anak-anak (Asnawir. 2002. hal. 105). Pelaksanaan dramatisasi dibutuhkan kerja sama antara pembimbing dengan anak-anak, karena langkah-langkah yang ideal akan menumbuhkan semangat dan minat belajar pada anak dalam mengelola emosi.

Perilaku sosial yang khas pada anak adalah imitasi/meniru, baik untuk mengenali maupun mengekspresikan emosi, sehingga orang dewasa memberikan keteladanan dan kesempatan pada anak-anak dalam mengelola emosi. Sehingga anak-anak akan mengidealkan orang-orang yang meraih keberhasilan melalui kerja keras, namun dikalangan orang tua ataupun pembimbing banyak yang belum menemukan cara ampuh untuk menanamkan ketrampilan kecerdasan emosional seperti: ketekunan, kerajinan, dan kemauan pada anak-anak (Shapiro, 1997: 245). Oleh karenaitu, dibutuhkan ketrampilan orang tua dalam memberikan bimbingan emosional yang disesuaikan dengan kebutuhan dan kondisi anak serta tumbuhnya keyakinan bahwa pengelolaan emosi akan mengoptimalkan kemampuankemampuan anak-anak. Kondisi tersebut menjadikan anak-anak percaya diri dalam belajar. Sehingga bimbingan emosional membantu anak-anak untuk mengelola emosi menjadi perilaku positif dalam mengembangkan semua kemampuan yang dibutuhkan ketika anak-anak memasuki usia sekolah (pendidikan formal) dengan lebih mengenali diri sendiri.

Anak-anak yang sukses dalam meraih kemandirian belajar dapat 36 dilihat dari kemampuan untuk mengenali diri dan menyesuaikan dengan 
lingkungan sosial. Menurut Santrock, perubahan-perubahan dapat dilihat dari tiga karakteristik pemahanan diri, yaitu:

- Karakteristik internal. Anak-anak cenderung mendefinisikan dirinya melalui keadaan dalam yang subyektif. Sehingga bimbingan emosional dilakukan agar anak-anak mengenali emosi dasar pada dirinya dan bagaimana reaksinya agar memberikan manfaat pada diri sendiri dan tidak merugikan orang lain. Karena emosi akan menimbulkan energi yang lebih sehingga akan mampu melakukan banyak aktivitas ketika diekspresikan pada hal yang positif. Misalnya, anak usia 8 tahun mendeskripsikan dirinya sebagai "Aku seorang yang pintar dan terkenal". Anak usia 10 tahun berkata tentang dirinya: "Aku cukup lumayan tidak khawatir terus menerus, aku biasanya suka marah, tapi sekarang aku sudah lebih baik". Kondisi seperti itu ketika anak mengenali berbagai emosi dan dasar dan keteladanan dalam ekspresi emosi.

- Aspek-aspek sosial, dalam suatu investigasi terhadap anak-anak seringkali menjadikan kelompok sosial sebagai acuan dalam deskripsi diri.

- Karakteristik perbandingan sosial. anak-anak cenderung membedakan diri sendiri dengan orang lain secara komparatif daripada absolut. Misalnya: tidak lagi berpikir tentang apa yang "aku lakukan atau tidak aku lakukan" tetapi cenderung berpikir "apa yang dapat aku lakukan daripada apa yang dapat dilakukan orang lain". Pergeseran perkembangan ini menyebabkan kecenderungan yang meningkat untuk membentuk perbedaan seseorang dengan orang lain (Desmita, 2013: 181).

Oleh karena itu, keberhasilan bimbingan emosional yang diberikan kepada anak-anak dapat diketahui melalui perubahan-perubahan kemampuan berpikir yang lebih rasional sesuai dengan kenyataan dalam menyelesaikan masalah kehidupan, tumbuhnya rasa nyaman karena mengenali potensi emosi dan semangat meraih cita-cita, serta tumbuhnya rasa percaya diri dalam mengekspresikan emosi dalam beradaptasi dengan lingkungan sesuai dengan norma.

\section{Penutup}

Fase anak-anak membutuhkan bimbingan orang dewasa (khususnya orang tua) dalam membantu mengenali potensi-potensi kemampuan yang dimiliki agar dapat menjalani semua tugas-tugas perkembangan. Potensi kecerdasan kognitif untuk menyelesaikan permasalahan, potensi afektif 37 
untuk menumbuhkan rasa nyaman dalam melaksanakan semua tugas kehidupan, sedangkan kecerdasan psikomotorik digunakan anak-anak untuk beradaptasi di lingkungan sosial. Namun dengan kecerdasan emosional, maka anak-anak akan nyaman dalam menyelesaikan masalah dan nyaman beradaptasi. Oleh karena itu, bimbingan emosional diberikan kepada anakanak agar mampu mengenali diri sendiri dan tumbuhnya kenyamanan dalam beradaptasi untuk memenuhi kebutuhan personal dan sosial. Bimbingan emosional lebih menenkankan untuk mengenali emosi dasar yang dimiliki oleh setiap manusia sejak lahir dan ekspresi emosi dapat diarahkan kepada perilaku yang positif dan memberikan manfaat (pribadi dan sosial). 


\section{DAFTAR PUSTAKA}

Adz-Dzaky, M. Hamdani Bakran. 2004. Konseling \& Psikoterapi Islam (Penerapan Metode Sufistik). Fajar Pustaka Baru. Jogyakarta.

Ahmadi, Abu dan Salimi, Noor. 2004. Dasar-dasar Pendidikan Agama Islam. Bumi Aksara. Jakarta.

Asnawir. 2002. Media Pembelajaran. Ciputat Pers. Jakarta.

Asril, Zainal, Micro Teaching, Jakarta: RajaGrafindo Persada, 2013.

Claproth, Richard, Dahsyatnya Bahaya Aktivasi Otak Tengah, Jakarta: Gramedia, 2010.

Desmita, Psikologi Perkembangan, Bandung: Remaja Rosdakarya, 2013.

Hamdani. 2012. Bimbingan dan Penyuluhan. Pustaka Setia. Bandung.

Mujib, Abdul dan Mudzakir, Jusuf, Nuansa-nuansa Psikologi Islam. Jakarta: RajaGrafindo. 20011

Rohmah, Noer, Pengantar Psikologi Agama, Yogyakarta: Teras, 2013.

Sarwono, Sarlito W, Pengantar Psikologi Umum, Jakarta: Rajawali Pers, 2012.

Shapiro, Lawrence E, Mengajarkan Emotional Inteligence pada Anak, Jakarta: Gramedia, 1997.

Syah, Muhibbin, Psikologi Belajar, Jakarta: RajaGrafindo Persada, 2011. 